\title{
Siirt ili kent merkezinde balık eti tüketim yapısı ve tüketicilerin satın alma eğilimlerinin belirlenmesi
}

\author{
Muammer KIRICI'1 , Oğuzhan ÇAM² ${ }^{2}$, Ersin KARAKAYA ${ }^{3}$
}

${ }^{1}$ Bingöl Üniversitesi Teknik Bilimler Meslek Yüksekokulu Veterinerlik Bölümü, BİNGÖL

${ }^{2}$ Siirt Üniversitesi Kurtalan Meslek Yüksekokulu Dış Ticaret Bölümü, Dıș Ticaret Programı, SİIRT

${ }^{3}$ Bingöl Üniversitesi Ziraat Fakültesi Tarım Ekonomisi Bölümü, BİNGÖL

Alınıș tarihi: 8 Mayıs 2018, Kabul tarihi: 17 Temmuz 2018

Sorumlu yazar: Ersin KARAKAYA, e-posta:karakayaersin1982@gmail.com

\section{Öz}

Bu çalıșma, Siirt'te balıketi tüketim yapısını belirlemek, kent merkezindeki bireylerin balık tüketim tercihlerini ve alıșkanlıklarını belirlemek için yapılmıştır. 2017 yılında yürütülen çalışmanın materyalini, Siirt kent merkezinde ikamet eden toplam 271 kişi ile yapılan anketlerden sağlanan veriler oluşturmaktadır. Veriler tanımlayıcı istatistikler, $\mathrm{X}^{2}$ testi ve Tek Yönlü Varyans (ANOVA) testleri kullanılarak analiz edilmiştir. Araştırma sonuçlarına göre; bireylerin $\% 22,5$ 'inin daha çok balıketi tükettikleri ve en çok tüketilen balık türünün ise hamsi olduğu sonucu bulunmuştur. Bireyler balıketini en çok ayda bir defa ve yaklaşık olarak 4,5 kg olarak tükettiklerini belirtmișlerdir. Bireylerin balıketi tüketim tercihlerinde balıketinin lezzetli olması ve besin değerinin yüksek olması faktörlerinin ön planda olduğu belirlenmiștir Bireylerin yarısının yeteri kadar balık tükettiklerine inanmadıkları sonucu ortaya çıkmıștır. Bireyler yeteri kadar balık tüketmemelerine neden olarak $\% 33,2$ oranında balık fiyatlarının pahalı olduğunu, \%25,8 oranında ise tüketmek istediği balık çeşidini bulamadığını belirtmişlerdir. Sonuç olarak; damak zevkine uygun her çeşit işlenmiş su ürünlerinin bulunabilirliği ve tüketicilere uygun fiyatlarla sunulması Siirt ilinde balık tüketiminin artması için son derece önem arz etmektedir.

Anahtar kelimeler: Aylık gelir, balık tüketimi, balık fiyatı, hamsi, Siirt
Fish meat consumption structure and determination of purchasing trends of consumers in Siirt city center

\begin{abstract}
This study was carried out to determine fish consumption structure and to reveal the preferences and habits of the individuals on fish consumption in center district of Siirt province. The data of 2017 year were obtained from 271 consumers through questionnaires. Data were analysed using descriptive statistics, $\mathrm{X}^{2}$ test and One-way ANOVA tests. According to research findings; it was found that $22.5 \%$ of the consumers consumed more fish than the average and the most consumed fish was anchovy. Consumers stated that they consumed fish at most once a month and approximately 4,5 kg. The findings showed that factors such as being delicious and having high nutritional value were preliminary in the fish consumption preferences of consumers. The consumers were in opinion that half of consumers had not enough fish consumption. The lack of consumption were due to high fish prices with $33.2 \%$ and not availability of desired fish type with $25.7 \%$. We believed that availability of varieties of processed aqua products suitable for all kinds of palate tastes and the prices offered to consumers would be critical in increasing the fish consumption quantity.
\end{abstract}

Key words: Monthly income, fish consumption, fish prices, anchovy, Siirt 


\section{Giriş}

Dünya nüfusunun artması, insan beslenmesinde son derece önemi bulunan hayvansal kökenli protein kaynaklarının azalmasına sebep olmuş ve bu protein açığını etkili ve ucuz olarak karşılamak için faydalanılacak kaynakların en önemlisi, su ürünleridir (Angiş, 2004; Aydın ve Karadurmuş, 2013; Beyazbayrak, 2014). Balıketinin protein açısından zengin ve tüm aminoasitleri içermesi, kolay sindirilebilmesi, insanlar için gerekli olan bütün vitaminleri dokularında bulundurmaları, büyüme ve sağlık için gerekli olan mineraller ve yağlar açısından sağlıklı ve dengeli beslenmede su ürünlerinin son derece önemli bir yeri vardır (Turan ve ark.,2006). Su ürünleri tüketimi çeşitli faktörlere bağlıdır bunlardan en önemlileri; ekonomik sınırlandırıcılar, ürünün sunuluş şekli ve yeme alışkanlığıdır (Girard ve ark., 1998; Aydın ve Karadurmuş, 2013 ). Özellikle bireylerin gelişme döneminde tüketilmesi son derece yararlı olan su ürünlerinin, Türkiye'de, bölgelere göre tüketim alışkanlıklarının değiştiği, farklı şekillerde ve oranlarda tüketildiği bilinmektedir (Atay ve ark., 2002; Aydın ve Karadurmuş, 2013; Beyazbayrak, 2014; Abdikoğlu ve ark., 2015).

2016 yılında Türkiye su ürünleri avcılık üretimi \%22.3 oranında azalarak 335.320 ton, su ürünleri yetiştiricilik üretimi ise \%5.4 artarak 253.395 ton olarak belirlenmiștir. Türkiye su ürünleri toplam üretimi 2016 yılında yaklaşık olarak \%12.4 azalmış ve 588.715 ton olarak gerçekleşmiştir. Türkiye su ürünleri iç tüketim miktarı 426.085 ton, balık unu ve yağ fabrikalarında işlenen miktar 93.096 ton, değerlendirilemeyen miktar 6139 ton ve kişi başı tüketim miktarı ise $5.4 \mathrm{~kg}$ olarak hesaplanmıştır (TÜIK, 2016). 2015 yılında Dünya Kişi başı balık tüketimi ortalaması $16 \mathrm{~kg}, \mathrm{AB}$ ortalaması ise $25 \mathrm{~kg}$ olarak belirlenmiştir.

Çizelge 1. 2015 yılı Dünya ve Türkiye su ürünleri üretimi

\begin{tabular}{cccccc}
\hline \multicolumn{7}{c}{ Dünya Su Ürünleri Üretimi (ton) } \\
\hline Deniz & $\begin{array}{c}\text { Avcllık (ton) } \\
\text { İçsu }\end{array}$ & Toplam & Deniz & Yetiştiricilik (ton) \\
İçsu & Toplam & Toplam (ton) \\
\hline 81.179 .323 & 12.525 .293 & 93.704 .616 & 27.879 .872 & 48.761 .154 & 76.641 .025 \\
\hline 397.731 & 34.176 & Türkiye su Ürünleri Üretimi (ton) & 170.345 .641 \\
& 431.907 & 138.879 & 101.455 & 240.334 \\
\hline
\end{tabular}

Kaynak: Gıda Tarım Hayvancılık Bakanlığı (GTHB) 2018

Türkiye'de tüketicinin gelir seviyesi su ürünlerinin fiyatı, tüketici tercihleri, tüketici alışkanlıkları, bölgenin sosyal ve ekonomik yapısı su ürünleri talebini ve tüketimini etkileyen faktörlerdir. Türkiye'de kişi başına yllık balık tüketiminin Doğu Anadolu, Güneydoğu Anadolu ve İç Anadolu Bölgesinde çok düşük, Karadeniz ve diğer kıyı bölgelerinde oldukça yüksek olması, Türkiye'de su ürünleri tüketim miktarının bölgeler açısından değiştiğinin bir göstergesidir. Mesela Karadeniz Bölgesi'nde yıllık kişi başına 25 kg civarında balık tüketilirken, Doğu ve Güney Doğu Anadolu Bölgesinde bu değer 1 kg'ın altında hesaplanmıștır (Erdal ve Esengün, 2008; Çadır ve Duman, 2013; Karakaya ve Kırıcı, 2016).

Türkiye'de su ürünleri tüketimi üzerine yapılmış çalışmalar çoğunlukla balık tüketim yapısının belirlenmesi üzerine odaklanmıştır (Sayılı ve ark., 1999; Şanslı ve Saygı, 2001; Hatırlı ve ark., 2004; Arık Çolakoğlu ve ark., 2006; Saygı ve ark., 2006; Cevger ve ark., 2008; Erdal ve Esengün, 2008; Orhan ve Yüksel, 2010; Yüksel ve ark., 2011; Aydın ve Karadurmuş, 2012; Aydın ve Karadurmuş, 2013; Balık ve ark., 2013; Çiçek ve ark., 2014; Olgunoğlu ve ark., 2014;
Abdikoğlu ve ark., 2015; Ercan ve Şahin, 2016; Karakaya ve Kırıcl, 2016; Terin ve ark., 2016; Gürel ve ark., 2017; Șen ve Şahin, 2017).

Balığın sağlıklı beslenme için faydaları hem de Türkiye'deki üretim potansiyeli ve sağlayacağı katma değer birlikte düşünüldüğünde, Türkiye'de balık tüketimini etkileyen faktörlerin belirlenmesine yönelik araştırmaların yapılması ve gerekli stratejilerin geliştirilmesi gereklidir. Bu çalışma, Siirt ili kent merkezinde tüketicilerin balıketi tüketim yapısı ve tüketicilerin satın alma eğilimlerinin belirlenmesi amacıyla yapılmıştır. Bu sayede Siirt ili kent merkezinde yaşayan tüketicilerin beslenme yapısında balıketinin yerinin belirlenmesi hedeflenmiştir.

\section{Materyal ve Metot}

$\mathrm{Bu}$ araştırmanın birincil verilerini Siirt kent merkezindeki tüketicilerden 2017 yllında elde edilen anket verileri oluşturmaktadır. İkincil veriler ise konu ile ilgili kamu kuruluşlarından, yerli ve yabancı bilimsel çalışmalardan, dergi ve çeşitli yayınlardan derlenmiştir. Siirt ili kent merkezinde yaşayan tüketicilerin balık tüketim alışkanlıklarının belirlenmesi amacıyla 
uygulanan ankette kişilere en fazla beğendikleri ve tercih ettikleri balık türü, tüketim miktarları, tercih sebepleri ve ürünleri pişirme şekilleri gibi konularda sorular sorulmuştur.

Örnek hacmini (anket yapılan tüketici sayısı) belirlemek için aşağıdaki formül kullanılmıştır (Baş, 2008; Gözener ve Sayılı, 2013).

$$
n=\frac{N \times t^{2} \times p \times q}{d^{2} \times(N-1)+t^{2} \times p \times q}
$$

Formülde;

n: Örneğe alınacak birey sayısı,

N: Hedef kitledeki birey sayısı (161 423),

p: İncelenen olayın gerçekleşme olasılığı (0.50),

q: İncelenen olayın gerçekleşmeme olasılığı (0.50),

t: Standart normal dağılım değeri (1.65),

d : Örnekleme hatası (0.05)'dır.

Formülde $\% 90$ güven aralığı, $\% 5$ hata payı ve maksimum örnek hacmine ulaşabilmek için $p=q=0.5$ olarak alınmış ve örnek hacmi 271 olarak hesaplanmiştır.

Anketten elde edilen veriler SPSS 17.0 (Statistical Package for Social Sciences) paket programında analiz edilmiştir. Analiz kapsamında, frekans tablolarl, pasta ve çubuk grafikler, $\chi 2$ testi, bağımsız örneklem t testi ve Tek Yönlü Varyans (ANOVA) Analizi'nden faydalanılmıştır. Tek Yönlü Varyans analizinde farklılığın hangi gruplardan kaynaklandığını belirlemek için Duncan testi kullanılmıştır.

\section{Bulgular ve Tartışma}

\section{Tüketicilerin sosyo demografik özellikleri}

Tüketicilerin \%54.2'sinin erkek, \%57.5'inin 34 yaşından küçük olduğu ve \%42.1'inin bekâr olduğu belirlenmiştir. 2016 yılında yapılmış olan Tüketici profili ve bilinç düzeyi araştırması sonuçlarına göre, tüketicilerin \%49,2'si 34 yaşın altında, tüketicilerin \%39,3'ü bekâr, tüketicilerin \%50,7'si erkek olarak belirlenmiştir. Çalışma sonuçları yapılan araştırma sonuçlarıyla benzerlik göstermektedir. TÜİK (2017) yılı verilerine göre, Siirt il nüfusunun \%61'inin 25 yaşın altında olduğu ve il nüfusunun oldukça genç yaştaki bireylerden oluştuğu sonucu belirlenmiștir. Çalışma sonuçları TÜİK verilerini destekler niteliktedir. Aylık geliri 1000 TL'nin altında olan bireylerin oranı ise \%29.5 olarak tespit edilmiştir. Babaoğul ve ark., (2016) tarafından Ankara'da yapılan Tüketici profili ve bilinç düzeyi araștırması sonucunda "1000 TL ve altında" gelire sahip olanların oranının \%5.9 olduğu sonucu çalışmada bulduğumuz değerden oldukça düşüktür. Tüketicilerin büyük kısmının (\%37.3) ön lisans mezunu olduğu belirlenirken okuryazar olmayan tüketici oranı ise \%7 olarak belirlenmiştir. Tüketici profili ve bilinç düzeyi araştırması kapsamındaki tüketicilerin \%29,8'i "lise", \%22,4'ü “lisans", \%19,8'i “ön lisans" düzeyinde öğrenim görmüş olup, "ilkokul ve daha az" düzeyde öğrenim görenlerin oranı \%11,6 olarak bildirilmiş çalışma sonuçları ile araştırma sonuçları farklılık göstermiştir. Ailedeki birey sayısının 1 ile 6 kişi arasında değiştiği ve ortalamasının 4.64 kişi olduğu saptanmıştır. Tüketici profili ve bilinç düzeyi araştırma kapsamına alınan tüketicilerin hane büyüklüğü ortalama 2.79 olarak hesaplanmış, bu değerin çalışmada bulunan değerden oldukça düşük olduğu görülmektedir. TÜİK (2016) verilerine göre, hanehalkı büyüklüğü Türkiye ortalaması 3.5 kişi olarak, TÜİK (2013) verilerine göre Siirt ili kent merkezi ortalama hanehalkı büyüklüğü ise 5.56 kişi olarak belirlenmiştir. Siirt ili hanehalkı büyüklüğü Türkiye ortalamasından yüksek, TÜİK (2013) değerinden ise düşük çıkmıştır. Tüketicilerin \%6.3'ü esnaf, \%5.2'si emekli, \%18.5'i serbest meslek, \%12.9'u işçi, \%21.8'i öğrenci, \%16.6'sı ev hanımı, \%15.1'i memur ve \%3.7'si ise çiftçi olarak belirlenmiştir.

\section{Tüketicilerin et tüketim tercihleri}

Tüketicilerin et tüketim tercihlerinin dağılımı şekil 1 'de verilmiştir. Tüketicilerin \%40.6'sı beyaz et, \%31.4'ü kırmızı et, \%22.5'i balık tükettiklerini ve $\% 5.5$ 'i ise et tüketmediklerini belirtmişlerdir. Arık Çolakoğlu ve ark., (2006) nın Çanakkale ilinde yaptığı bir çalışmada, ankete katılan kişilerin en çok beyaz eti (\%47.5), sonra balık etini (\%29.85) ve son olarak ta kırmızı eti (\%22.05) tükettikleri tespit edilmiştir. Olgunoğlu ve ark (2014) tarafından yapılan çalışmada, bireylerin \%56'sının tavuk eti, \%38'inin kırmızı et, \%5'inin balıketi tükettikleri, \%1'inin ise et ürünleri tüketmedikleri belirlenmiştir. Ağrı İli Merkez İlçede yapılan bir çalışmada, tüketicilerin et tüketim tercihlerinin dağılımı incelendiğinde, tavuk eti tüketenlerin oranı \%53.6, kırmızı et tüketenlerin oranı \%35.7, balık tüketenlerin oranı \% 7.3 ve kabuklu (midye vb) tüketenlerin oranı \% 3.2 olarak belirlenmiştir (Gürel ve ark., 2017). Çalışma bulguları diğer çalışma bulgularıyla birebir uyumlu sonuç ortaya koymuştur. Yüksel ve ark (2011)'nın yürütmüş olduğu çalışmada, en fazla beğenilen et türünün \%48 oranında balıketi olmasına rağmen en az tüketilen et türünün de \%22 oranında balıketi olduğu, bireylerin en fazla kırmızı et (\%40) tükettikleri sonucu belirlenmiştir. 
Trabzon ve Giresun illerinde yapılan bir çalıșmada tüketicilerin \%41'inin su ürünleri, \%33'ünün kanatlı ve $\% 26$ 'sının ise kırmızı et tükettikleri bildirilmiștir (Aydın ve Karadurmuş, 2013). Beyazbayrak (2014) tarafından yapılan çalışmada, bireylerin et tüketim tercihinde ilk sırayı \%55 ile kırmızı et, 2.sırayı \%36.3'le tavuk, 3.sırayı ise \%6 ile balık almıștır. Katılımcıların \%2.7'si hiçbir çeşit et tüketmemektedir. Elazı̆̆ ilinde Çiçek ve ark (2014)'nın yapmış olduğu çalışmada, tüketicilerin \%41'inin kırmızı eti, \%23'ünün beyaz eti (kanatlı), \%3'ünün balıketi ve $\% 32$ 'sinin her üç et türünü de tükettiği, \%1'inin ise hiçbir hayvansal ürünü tüketmedikleri tespit edilmiştir. Şen ve Şahin (2017) tarafından Mersin'de yapılan çalışmada, tüketicilerin tüketim tercihleri kırmızı et (\%44), balıketi (\%38) ve tavuk eti (\%18) olarak belirlenmiştir. Çalışma bulguları diğer çalışma bulgularıyla farklı sonuç ortaya koymuştur. Tüketicilerin sosyo demografik özellikleri ile tüketilen et türü arasındaki farklıkların önemli olup olmadığı analiz edilmiş, sonuç olarak eğitim durumları ve tüketilen et türü arasındaki farkların önemli olduğu, yüksek lisans mezunu olan bireylerin diğer bireylere nazaran daha fazla balık tükettiği sonucu belirlenmiştir ( $\mathrm{F}=2.182 ; \mathrm{P}=0.02)$.

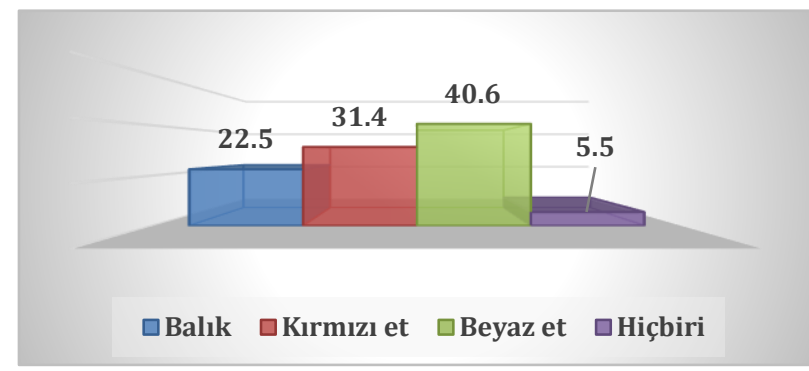

Şekil 1. Tüketicilerin et tüketim tercihleri (\%)

\section{Tüketicilerin aylık balık tüketimleri ve tüketim tercihleri}

Tüketicilerin \%72'si 6 kg'dan az, \%19.9'u 6-10 kg arasında ve $\% 8.1^{\prime} \mathrm{i}$ ise $11 \mathrm{~kg}$ ve üzerinde balıketi tükettikleri belirlenirken, aylık hane halkı ortalama balık tüketim miktarı $4.5 \mathrm{~kg}$, aylık kişi başı ortalama balık tüketim miktarı $0.97 \mathrm{~kg}$, yıllık hane halkı ortalama balık tüketimi $=54 \mathrm{~kg}$ ve yıllık kişi başı ortalama balık tüketimi ise $11.7 \mathrm{~kg}$ olarak belirlenmiştir (Çizelge 2). Arık Çolakoğlu ve ark (2006) tarafından yapılan çalışmada, bireylerin büyük kısmının (\%87.46) ayda 1-6 kg arasında balık tükettikleri bildirilmiștir. Çalışma bulguları Çolakoğlu ve ark (2006)'nın çalışma bulgularıyla uyumlu sonuç ortaya koymuştur. Olgunoğlu ve ark (2014) tarafından Adıyaman da yapılan çalışmada, aylık kişi başı balık tüketimi 3.01 kg, Aydın ve Karadurmuş (2013) tara- findan Trabzon ve Giresun da yapılan çalışmada, aylık kişi başı balık tüketimi $2.46 \mathrm{~kg}$, Abdikoğlu ve ark (2015) tarafından Tekirdağ da yapılan çalışmada aylık kişi başı balık tüketimi $1.22 \mathrm{~kg}$, Terin ve ark (2016) tarafından Van'da yapılan çalışmada aylık kişi başı balık tüketimi $1.4 \mathrm{~kg}$, olarak belirlenmiştir. Çalışmada bulduğumuz değer $(0.97 \mathrm{~kg})$ diğer çalışma bulgularından düşüktür. Erdal ve Esengün (2008) tarafından Tokat'ta yapılan çalışmada, yıllık kişi başına balık tüketim miktarı $13 \mathrm{~kg}$ olarak bildirilmiş, bu değer çalışmada bulduğumuz değerden (11.7) yüksektir. Beyazbayrak (2014) tarafından Kahramanmaraş ilinde yapılan çalışmada, yıllık kişi başına düssen balık tüketimi yaklaşık 6 kg olarak hesaplanmış ve çalışmada bulduğumuz değerden oldukça düşüktür. Ercan ve Şahin (2016) tarafından Kahramanmaraş'ta yapılan bir başka çalışmada ise aylık kişi başı ortalama balık tüketim miktarı $0.344 \mathrm{~kg}$ olarak tespit edilmiş, bu değer çalışmada bulduğumuz değerden (0.97) düşüktür.

Karakaya ve Kırıcı (2016) tarafından Bingöl ili kent merkezinde yapılan çalışmada, hane halklarının ortalama balık tüketim miktarı $4.88 \mathrm{~kg} /$ ay ve kişi başı ortalama balık tüketim miktarı $12.2 \mathrm{~kg} /$ yıl olarak saptanmış, bulunan değerler çalışmada bulduğumuz değerlerden (4.5 ve 11.7) yüksektir. Çiçek ve ark (2014) tarafından Elazığ'da kişi başına yıllık balık tüketimi $3.30 \mathrm{~kg}$, Yüksel ve ark (2011) tarafından Tunceli'de yapılan çalışmada, kişi başı yıllık balık tüketimi $4.1 \mathrm{~kg}$ olarak hesaplanmış bulunan değerler çalışmada bulunan değerin (11.7) oldukça altındadır. Yapılan Khi kare bağımsızlık testi sonucunda, tüketilen aylık su ürünleri miktarı ile yaş grupları arasında anlamlı bir ilişki belirlenmiş $\left(X^{2}=29.498 ; P=0.04\right) 34$ yaşından küçük olan bireylerin diğer bireylere nazaran daha az balık tükettikleri belirlenmiştir. Meslek grupları ile aylık balık tüketim miktarı arasında da anlamlı bir ilişki saptanmış, emekli ve esnafların $11 \mathrm{~kg}$ ve üzerinde balık tüketmediği, memurların ise diğer meslek gruplarına göre daha az balık tükettikleri sonucu belirlenmiștir $\left(\mathrm{X}^{2}=35.171 ; \mathrm{P}=0.02\right)$. Gürel ve ark (2017) tarafindan yapılan çalışmada da benzer şekilde, balık tüketim durumuna göre meslek grupları bakımından gruplar arasında istatistiki olarak önemli fark bulunmuştur. Karakaya ve Kırıcı (2016)'nın Bingöl'de yaptıkları çalışmada yaş grupları ile balık tüketim durumu arasında ki iliş̧i anlamlı bulunurken, meslek grupları ile balık tüketimi arasında ki ilişsi anlamlı bulunmamıștır. Tüketicilerin ne kadar sıklıkla balık tükettiklerinin oransal dağılımı şekil 2'de verilmiştir. 
Çizelge 2. Tüketicilerin aylık balık tüketimleri

\begin{tabular}{ccc}
\hline Aylık tüketilen balık miktarı & Sayı & Oran (\%) \\
\hline 6 kg'dan az & 195 & 72.0 \\
6-10 kg arası & 54 & 19.9 \\
11 kg ve üzeri & 22 & 8.1 \\
Toplam & 271 & 100.0 \\
\hline
\end{tabular}

Aylık hane halkı ortalama balık tüketim miktarı $=4.5 \mathrm{~kg}$ Aylık kişi başı ortalama balık tüketim miktarı $=0.97 \mathrm{~kg}$ Yıllık hane halkı ortalama balık tüketimi $=54 \mathrm{~kg}$ Yıllık kiși bașı ortalama balık tüketimi= $11.7 \mathrm{~kg}$

Haftalık ve 15 günde bir balık tüketenlerin oranları birbirine yakın ve sırasıyla $\% 26.2$ ve $\% 26.5$ olarak belirlenmiștir. Tüketiciler balığı daha çok (\%32.5) ayda bir defa tükettiklerini belirtirken, balık tüketim sıklığı olarak diğer seçeneğini işaretleyen tüketicilerin (\%14.8) balığı daha çok özel günlerde tükettikleri sonucu belirlenmiştir. Tekirdağ ilinde yapılan bir çalışmada, tüketicilerin ortalama balık tüketim sıklığ $\% 60.6$ oranında 15 günde bir olarak hesaplanmıştır (Abdikoğlu ve ark., 2015). Terin ve ark (2016) tarafından Van'da yapılan bir araştırmada, on beş günde bir balık tüketilme oranı $\% 30.6$, haftada bir balık tüketilme oranı $\% 30.2$, ayda bir balık tüketilme oranı \%25.4 ve haftada birden fazla balık tüketilme oranı \%13.8 olarak belirlenmiştir. Ordu ili Fatsa ve Aybastı ilçelerinde Balık ve ark. (2013)'nın yürütmüş olduğu çalışmada, her iki ilçede de haftada bir balık tüketme oranı eşit çıkmış (\%34.8), 15 günde bir balık tüketme oranı ise Fatsa için \%36.7, Aybastı ilçesi için ise \%36.5 olarak birbirine yakın değerler olarak bildirilmiştir. Şen ve Şahin (2017) Mersinde yaptıkları çalışmada tüketicilerin \%43'ünün haftada bir, \%42'sinin ise ayda bir balık tükettiklerini bildirmişlerdir. Çanakkale de yapılan bir çalışmada, tüketicilerin yaklaşık \%43-46 arasında haftada en az bir kez balık tükettikleri bildirilmiştir (Arık Çolakoğlu ve ark., 2006). Karakaya ve Kırıcı (2016)'nın Bingöl'de yürütmüș oldukları çalıșmada, tüketicilerin \%35.1'inin 15 günde bir, \%33.2'sinin ayda bir, $\% 18.5$ 'inin haftalık ve \%13.2'sinin ise özel günlerde balık satın aldığı belirlenmiştir. Çalışma bulguları diğer çalışma bulgularından kısmen farklı sonuç ortaya koymuş, özellikle ayda bir balık tüketilme oranının çalışmada yüksek çıkmasının en önemli nedeninin tüketicilerin düşük gelire sahip olması olarak düşünülebilir.

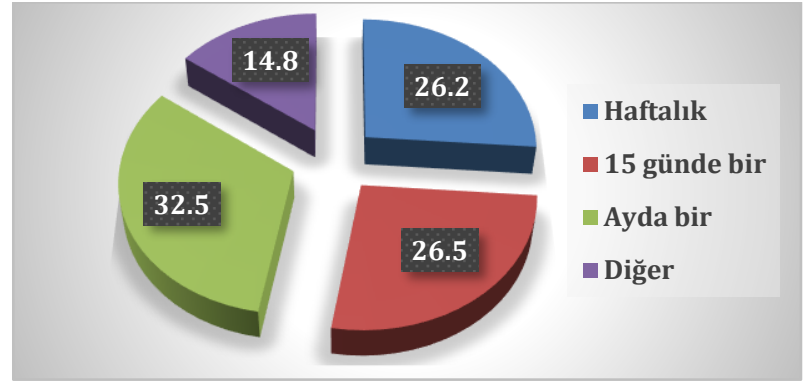

Şekil 2. Balık tüketim sıklığı (\%)

Tüketicilerin büyük bir kısmının (\%57.6) balıketi tercih etmelerinde öncelikli nedenin lezzetli olması faktörünün olduğu belirlenirken, bu faktörü \%21.8 oranla besin değerinin yüksek olması faktörünün izlediği belirlenmiştir. Balıketi tercih nedeni olarak düşük kolesterollü olması faktörünün oranı \%5.9, ucuz olması, kolay bulunması ve diğer faktörlerin oranı $\% 3.3$, kalite ve güven faktörünün oranı $\% 3$ ve alışkanlık faktörünün oranı ise \%1.8 olarak saptanmıştır (Şekil 3). Aydın ve Karadurmuş (2013) yaptıkları çalışmada balıketi tercihinde sağlık faktörünün oranını \%45.9 ve lezzet faktörünün oranını ise \%34 olarak bildirmişlerdir. Tekirdağ'da yapılan bir çalışmada, balık tüketiminde sağlık faktörünün öncelikli neden olma oranı \%72.3, lezzet faktörünün öncelikli neden olma oranı ise \%21.9 olarak tespit edilmiştir (Abdikoğlu ve ark., 2015). Karakaya ve Kırıcı (2016)'nın Bingöl'de yaptıkları araştırmada, tüketicilerin balık tercihindeki öncelikli nedeni \%60.1 ile lezzetli olması olurken, balık tercihinde ucuz olması ve kolay bulunması gibi nedenlerin oranı oldukça düşük (\%1.2) bulunmuştur. Yüksel ve ark. (2011)'nın Tunceli'de yaptıkları çalışmada, balık tercihinde lezzet faktörünün oranı çalışmamıza nazaran çok düşük (\%7), Çadır ve Duman (2013) tarafindan Elâzı ğ'da yapılan çalışmada ise balık tercihinde lezzet faktörünün oranı çalışmamızla benzer (\%59.7) bulunmuştur. Tüketicilerin mevsimler itibariyle balık tüketimlerinin ve balık tüketim şekillerinin dağılımı şekil 4'te verilmiştir. Tüketicilerin \%48.7'si sonbahar aylarında balık tüketirken, \%26.2'si yaz aylarında, \%16.6'sı kış aylarında ve $\% 8.5$ 'i ise ilkbahar aylarında balık tükettiklerini belirtmişlerdir. Balık tüketim şekli olarak tavada tüketim şeklinin oranı \%31.7 ile en çok çıkarken bunu sırasıyla \%29.2 ile kızartma ve \%22.5 ile ızgara şekli izlemiştir. Tüketicilerin çok az bir kısmı (\%0.7) balığı buğulama şeklinde tükettiklerini ifade etmişlerdir. 


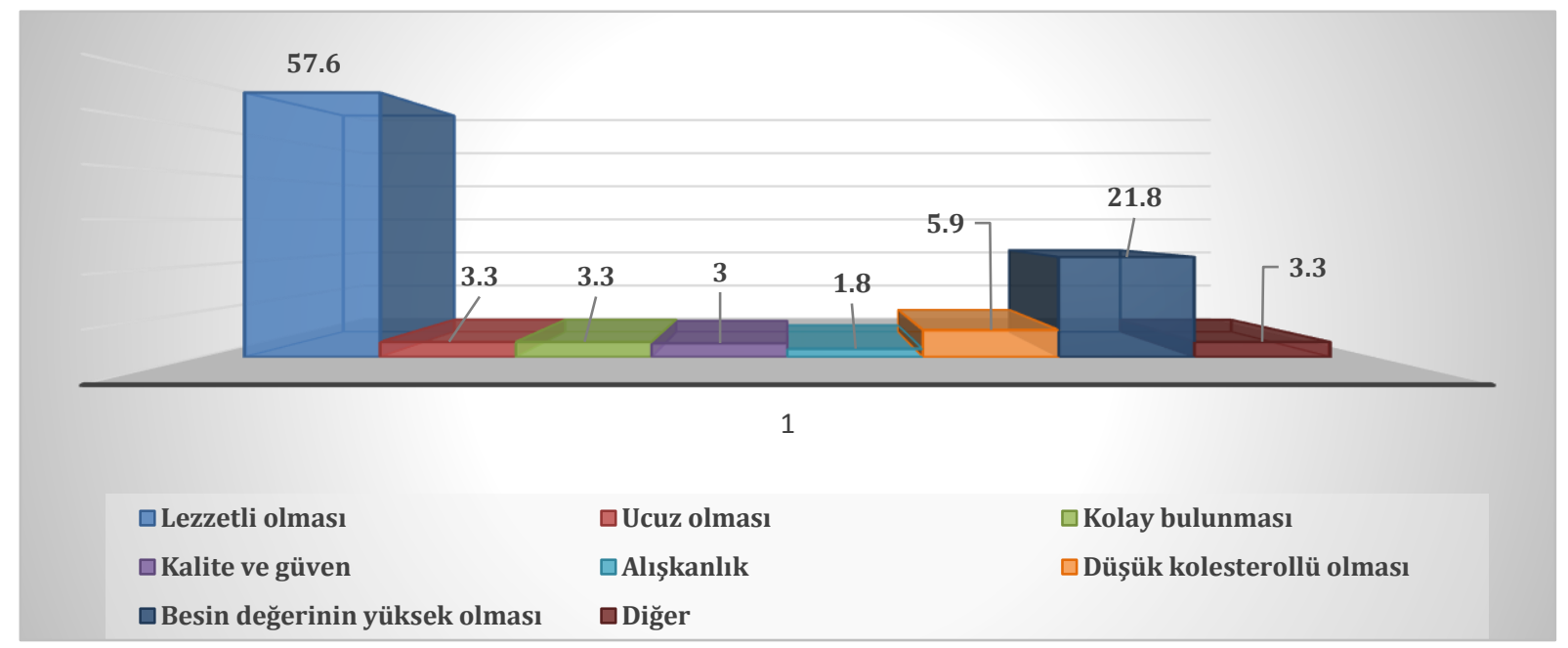

Şekil 3. Tüketicilerin balıketi tercihinin öncelikli nedeni (\%)

Adıyaman'da Olgunoğlu ve ark (2014)'nın yürütmüş olduğu çalışmada, tüketicilerin \%71'i kışın, \%13’ü sonbaharda balık tükettiklerini, balık tüketim şeklinde \%41 oranında kızartma, \%35 oranında firın ve $\% 23$ oranında ise ızgara şeklini tercih ettiklerini belirtmişlerdir. Trabzon ve Giresun illerinde yapılan bir çalışmada balığın tüketim şekli olarak kızartmanın oranı \%52.9, ızgaranın oranı \%29.7 ve buğulamanın oranı ise \%12.9 olarak tespit edilmiştir (Aydın ve Karadurmuş, 2013). Abdikoğlu ve ark (2015) tarafından Tekirdağ'da yapılan çalışmada balığın en çok (\%34.7) kış mevsiminde tüketildiği bildirilmiştir.
Van'da Terin ve ark (2016) yaptıkları çalışmada balığın en çok (\%84.1) kışın ve en çok (\%40.2) kızartma şeklinde tüketildiğini saptamışlardır. Bingöl'de yapılan bir çalışmada tüketicilerin büyük bir kısmının (\%84.4) balığı kışın tükettikleri ve tüketim şekli olarak ise büyük bir kısmının (\%42.8) firında seçeneğini tercih ettikleri belirlenmiştir (Karakaya ve Kırıcı, 2016). Çalışma bulguları daha önce yapılmış olan çalışma bulgularıyla farklı sonuçlar ortaya koymuş, balık tüketim mevsiminin ve tüketim şeklinin bölgeler itibariyle farklılıklar gösterdiği sonucu ortaya çlkmıştır.

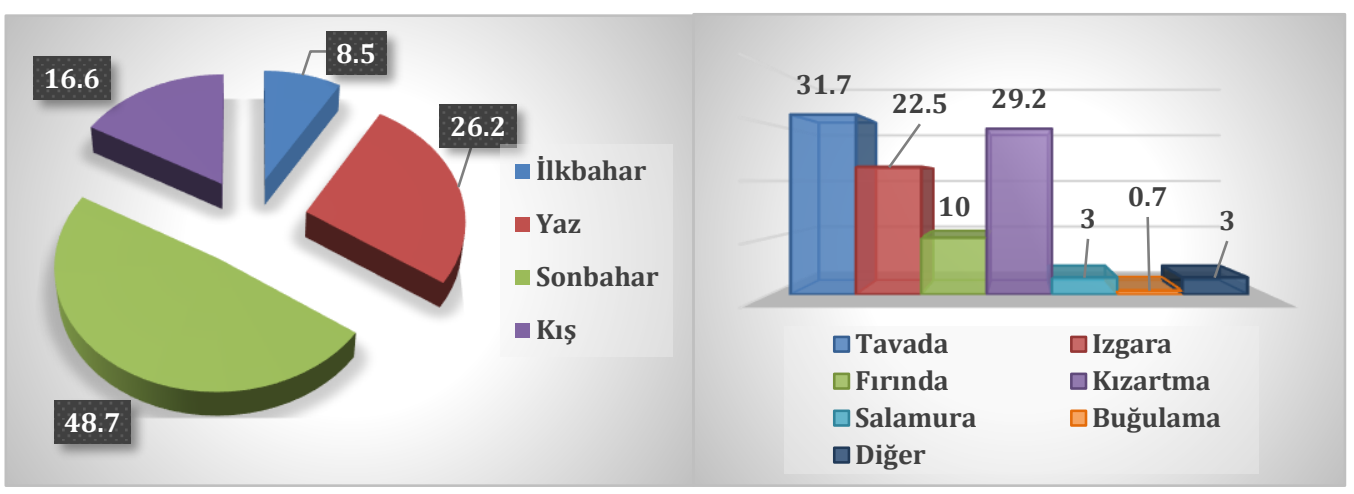

Şekil 4. Mevsimler itibariyle ve tüketim şekli olarak balık tüketimi (\%)

Tüketicilerin \%47.6'sı deniz balıklarını, \%32.2'si çay/dere/akarsu balıklarını, \%11.4'ü okyanus balıklarını ve \%8.8'i ise diğer balıkları özellikle havuz kafes ve göl balıklarını tüketmeyi tercih ettiklerini belirtmiş, en çok tüketilen balık türünün \%42.1 ile hamsi olduğu belirlenmiştir. Alabalığın tüketiciler tarafından tercih edilme oranı \%23.6, diğer balık türlerinin (çupra, çinakop ve somon gibi) tercih edilme oranı \%13.3, Palamutun tercih edilme oranı
$\% 10.7$ ve İstavritin tercih edilme oranı ise \%10.3 olarak tespit edilmiştir (Şekil 5). Adıyaman'da yapılan çalışmada tüketicilerin daha çok (\%70) tatlı su balıklarını tüketmeyi tercih ettikleri ve deniz balıkları içinde ise Hamsinin \%19 ile ilk sırada tercih edildiği belirlenmiştir (Olgunoğlu ve ark., 2014). Aydın ve Karadurmuş (2013) tarafından Trabzon ve Giresun'da yapılan araştırmaya göre su ürünleri arasında en çok hamsinin (\% 17.75) tercih edildiği sonucu 
bildirilmiștir. Sarı ve ark. (2000) ve Güngör (2014), Van'da yürüttükleri araștırmalarda da tüketicilerin en çok hamsiyi tercih ettikleri tespit edilmiştir. Daha önce yürütülen diğer çalışmalarda da tüketicilerin en çok tercih ettikleri balık çeșitleri Çanakkale'de istavrit, hamsi, sardalye ve çipura, (Arık Çolakoğlu ve ark., 2006), Konya'da hamsi, palamut ve somon, Mersin'de hamsi, çipura ve levrek Şen (2011), İzmir'de levrek, sardalye, hamsi ve istavrit Çaylak (2013), Edirne'de hamsi, palamut, uskumru ve levrek Onurlubaş (2013), Amasya'da hamsi, mezgit, istavrit, çipura ve palamut, Nalinci (2013), Antakya'da hamsi, çipura levrek ve alabalık Can ve ark. (2015) ve Ankara'da hamsi, çipura ve alabalık (Gül Yavuz ve ark., 2015) tır. Terin ve ark. (2016) Van'da hanelerin en çok tüketmeyi tercih ettikleri balık çeşitlerinin sırası ile hamsi, alabalık ve inci kefali olduğunu belirlemiştir. Sonuç olarak yapılan birçok araştırmada hanelerin ilk sırada tükettiği balık türü hamsi olarak belirlenmiştir. Çalışmada elde edilen sonuçta bu durumla paralellik göstermektedir.

Çizelge 3. Balık satın alınan yer, istenilen balık çeşidinin piyasada bulunabilmesi, yeteri kadar balık tüketimine inanma durumu ve

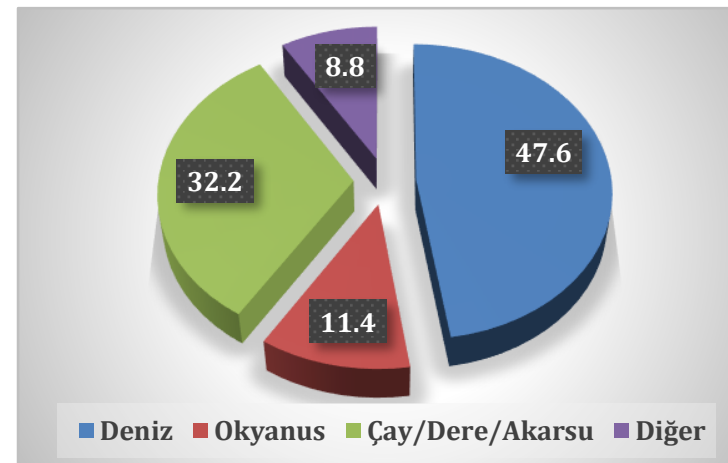

Şekil 5. Tüketimi tercih edilen balık türü (\%)

Tüketicilerin, \%48.3'ü balı̆ğ sabit balık satıcısından aldığını, \%38.4'ü istediği balık çeşidini piyasada bazen bulduklarını \%3.3'ü ise istediği balık çeşidini piyasada bulamadığını ifade etmişlerdir. Tüketicilerin yarısına yakını (\%48.7) yeteri kadar balık tükettiklerine inanmadıklarını buna neden olarak ise \%33.2 oranında balık fiyatlarının pahalı olduğunu, \%25.8 oranında ise tüketmek istediği balık çeşidini bulamadığını belirtmişlerdir. Tüketicilerin \%43.6'sı balık fiyatlarını normal bulduklarını ifade etmişlerdir (Çizelge 3). Karakaya ve Kırıcı (2016) Bingöl'de yaptıkları çalışmada, tüketicilerin \%75.3'ünün sabit balık satıcısından balık aldığını ve bu durumun en büyük nedeninin tüketicinin sabit balık satıcısına balık fiyatları hakkındaki görüşü değişkenlerinin dağılımı

\begin{tabular}{lc}
\hline Değişkenler & Oran (\%) \\
\hline Balık satın alınan yer & \\
\hline Kendim tutarım & 3.3 \\
Sokak satııısı & 22.1 \\
Sabit satıcı & 48.3 \\
Balık yetiștiricisi & 11.1 \\
Süpermarket & 9.2 \\
Diğer & 5.9 \\
\hline İstenilen balık çeşidinin piyasada bulunabilmesi & \\
Hayır & 3.3 \\
Az & 22.5 \\
Bazen & 38.4 \\
Çok & 25.5 \\
Oldukça çok & 10.3 \\
\hline Yeteri kadar balık tüketimine inanma durumu & \\
\hline Hayır & 22.9 \\
Az & 25.8 \\
Kısmen & 32.5 \\
Çok & 11.8 \\
Oldukça çok & 7.0 \\
\hline Balık fiyatları hakkındaki görüș & \\
\hline Ucuz & 8.1 \\
Normal & 43.6 \\
Pahalı & 33.2 \\
Fikrim yok & 15.1 \\
\hline
\end{tabular}

42.1

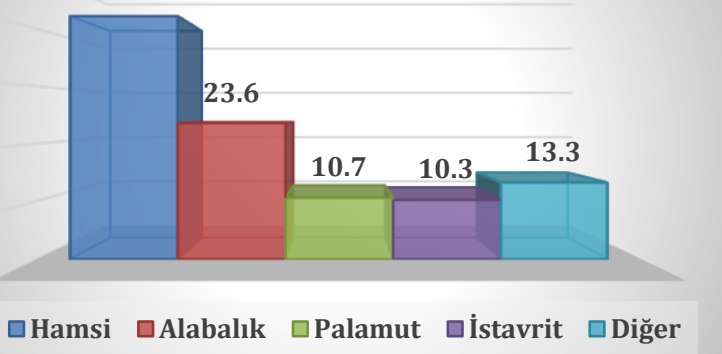

olan güveninden kaynaklandığını bildirmiş, ayrıca tüketicilerin \%51.4'ünün balık fiyatlarını normal buldukları sonucunun da çalışma sonuçlarımızla birebir uyumlu olduğunu göstermektedir. Ceylan (2006) ve Terin ve ark (2016) tarafindan Van ilinde yapılan çalışmalarda, tüketicilerin tüketilen balık miktarını yeterli bulma oranı sırasıyla, $\% 56.2$ ve \%56.5 birbirine çok yakın değerler olarak bulunmuştur. Nalinci (2013) aynı değeri Amasya için oldukça yüksek (\%73) olarak belirlerken, Gül Yavuz ve ark (2014) aynı değeri Ankara için \%41.3 olarak bildirmiştir. Çalışmada bulduğumuz değerin diğer çalışmalarda bulunan değerlerden çok düşük olduğu bu durumun en önemli sebeplerinden biri, Siirt ili 
kent merkezindeki tüketicilerin tüketmek istedikleri balık çeşitlerini piyasada bulamamaları olarak görülebilir.

\section{Sonuç ve Öneriler}

Tüketicilerin \%40.6'sının beyaz et, \%31.4'ünün kırmızı et, $\% 22.5$ 'inin balık tükettikleri ve $\% 5.5$ 'inin ise et tüketmedikleri belirlenmiş, yüksek lisans mezunu olan bireylerin diğer bireylere nazaran daha fazla balık tükettiği sonucu saptanmıştır. 34 yaşından küçük olan bireylerin diğer bireylere nazaran daha az balık tükettikleri, emekli ve esnafların $11 \mathrm{~kg}$ ve üzerinde balık tüketmediği, memurların ise diğer meslek gruplarına göre daha az balık tükettikleri sonucu belirlenmiştir. Tüketicilerin aylık hane halkı ortalama balık tüketim miktarı $4.5 \mathrm{~kg}$, aylık kişi başı ortalama balık tüketim miktarı $0.97 \mathrm{~kg}$, yıllık hane halkı ortalama balık tüketimi, $54 \mathrm{~kg}$ ve yıllık kişi başı ortalama balık tüketimi ise $11.7 \mathrm{~kg}$ olarak hesaplanmış bu değerin TÜIK (2017) yılı Türkiye kişi başı balık tüketimi değerinden (5.49 kg/yll) yüksek olduğu belirlenmiştir. Tüketiciler balığı daha çok (\%32.5) ayda bir defa tükettiklerini belirtirken, ayda bir balık tüketilme oranının çalışmada yüksek çıkmasının en önemli nedeninin tüketicilerin düşük gelire sahip olması olarak düşünülebilir. Tüketicilerin büyük bir kısmının (\%57.6) balıketi tercih etmelerinde öncelikli nedenin lezzetli olması faktörünün olduğu belirlenirken, çalışma bulgularından hareketle tüketicilerin balıketi tüketim tercihlerinde lezzet ve besin değeri gibi önemli faktörleri ilk sırada göz önünde bulundurmaları balıketi tüketimi konusunda bilinçli oldukları ancak balıketinin fiyatı ve kolay bulunması açısından ise tüketim açısından çaresiz kaldıkları sonucuna varılabilir. Tüketicilerin büyük bir kısmı (\%48.7) sonbahar aylarında balık tüketirken, balık tüketim şekli olarak ise tavada tüketim şeklinin oranı \%31.7 ile en çok çıkarken, balık tüketim mevsiminin ve tüketim şeklinin bölgeler itibariyle farklılıklar gösterdiği sonucu ortaya çıkmıștır. Tüketiciler daha çok deniz balıklarını (\%47.6), tüketmeyi tercih ettiklerini belirtmiş, en çok tüketilen balık türünün \%42.1 ile hamsi olduğu belirlenmiștir. Tüketicilerin, $\% 48.3$ 'ü balığı sabit balık satıcısından aldığını, \%38.4'ü istediği balık çeșidini piyasada bazen bulduklarını, tüketicilerin yarısına yakını (\%48.7) yeteri kadar balık tükettiklerine inanmadıklarını buna neden olarak ise \%33.2 oranında balık fiyatlarının pahalı olduğunu, \%25.8 oranında ise tüketmek istediği balık çeşidini bulamadığını belirtmişlerdir. Tüketicilerin \%43.6'sı balık fiyatlarını normal bulduklarını ifade etmişlerdir.
Balıketinin sağlıklı ve dengeli beslenme için faydalarının tüketicilere anlatılması için stratejilerin belirlenerek, Siirt ilinde balık tüketim miktarının artırılması hedeflenmelidir. Tüketicilere bütün mevsimlerde balık tüketme imkânları sağlanmalıdır, bundan dolayı damak zevkine uygun işlenmiş bütün su ürünleri çeşitlerini piyasada bulundurmak ve tüketicilere uygun fiyatlarla arz etmek gereklidir. Deniz ürünleri üretiminin ve kültür balıkçılığının desteklenmesi son derece önemlidir. Sonuç olarak; her türlü damak zevkine uygun işlenmiş su ürünleri çeşitlerinin bulunabilirliği ve tüketicilere uygun fiyatlarla sunulması Siirt ilinde balık tüketiminin artması için son derece önem arz etmektedir.

\section{Kaynaklar}

Abdikoğlu, D. İ., Azabağaoğlu, M. Ö., Unakıtan, G., 2015. Tekirdağ ilinde balık tüketim eğilimlerinin belirlenmesi. Balkan and Near Eastern Journal of Social Sciences 01 (01)

Angiş, S., 2004. Gökkuşağı Alabalığında Soğuk Tütsülemenin Bazı Önemli Kimyasal Ve Duyusal Özellikler Üzerine Etkisi. Atatürk Üniversitesi, Fen Bilimleri Enstitüsü, Yüksek Lisans Tezi, Erzurum, 36 s.

Atay, D., Aydın, F., Yavuzcan Yıldız, H., 2002. Su Ürünleri Yetiştirme İlkeleri. Ankara Üniversitesi Ziraat Fakültesi Yayınları, Ankara, 270 s.

Aydın, M., Karadurmuș, U., 2012. Consumer behaviors for seafood in Ordu province. SUMAE Yunus Araștirma Bülteni, 3: 18-23.

Aydın, M., Karadurmuş, U., 2013. Trabzon ve Giresun Bölgelerindeki su ürünleri tüketim alışkanlıkları. Karadeniz Fen Bilimleri Dergisi, 3(9): 57-71.

Babaoğul, M., Şener, A., Buğday, E. B., 2016. Tüketici profili ve bilinç düzeyi araştırması. T.C. Gümrük ve Ticaret Bakanlı̆̆l, Tüketici Akademisi Projesi (http://www.consumeracademy.gov.tr). (Erişim tarihi: 12.08.2018).

Balık, İ., Yardımcı, C., Turhan, O., 2013. Comparatively investigation of fish consumption habits of people in Fatsa and Aybastı districts of Ordu province (in Turkish with English abstract). Ordu Univ. J. Sci. Tech, 3(2): 18-28.

Baş, T., 2008. Anket. Araştırma Yöntemleri Dizisi: 2. Seçkin Yayıncılık, 5. Baskı, Ankara, 255 s.

Beyazbayrak, Z., 2014. Kahramanmaraş İli Merkez İlçede Balık Tüketim Alışkanlıkları. Yüksek Lisans Tezi. Kahramanmaraş Sütçü İmam Üniversitesi, Fen Bilimleri Enstitüsü, Kahramanmaraş. $58 \mathrm{~s}$. 
Can, M. F., Günlü, A., Can, H. Y., 2015. Fish consumption preferences and factors influencing it. Food Science and Technology, 35(2): 339-346.

Cevger, Y., Aral, Y., Demir, P., Sarı̈zkan, S., 2008. Ankara Üniversitesi Veteriner Fakültesi intern öğrencilerinde hayvansal ürünlerin tüketim durumu ve tüketici tercihleri. Ankara Üniversitesi Veteriner Fakültesi Dergisi, 55: 189-194.

Ceylan, M., 2006. Van İli Kentsel Ve Kirsal Alanda Et Ve Ürünleri Tüketim Yapısı Ve Tüketicilerin Satın Alma Eğilimleri. Yüksek Lisans Tezi. YYÜ. Fen Bilimleri Enstitüsü, Van. $71 \mathrm{~s}$.

Çadır, F., Duman, M., 2013. Keban baraj gölü ova bölges halkının balık tüketim alışkanlıklarının araştırılmasl. Fırat Üniversitesi Fen Bilimleri Dergisi. 25(1): 61-70.

Çaylak, B., 2013. İzmir İli Su Ürünleri Tüketimi ve Tüketici Tercihleri Üzerine Bir Araștırma. Yüksek Lisans Tezi, Çanakkale Onsekiz Mart Üniversitesi Fen Bilimleri Enstitüsü, Çanakkale. $62 \mathrm{~s}$.

Çiçek, E., Akgün, H., İlhan, S., 2014. Determination of fish consumption habits and preferences in Elazığ province (in Turkish with English abstract). Yunus Research Bulletin, 1: 3-11.

Çolakoğlu, F. A., İşmen, A., Özen, Ö., Çakır, F., Yığın, Ç., Ormancı, H. B., 2006. Çanakkale İlindeki su ürünleri tüketim davranışlarının değerlendirilmesi. Ege Üniversitesi Su Ürünleri Dergisi, 23(3): 387-392.

Ercan, O., Şahin, A., 2016. Kahramanmaraş kent merkezinde balık eti tüketim analizi. KSÜ Doğa Bilimleri Dergisi, 19(1): 51-65.

Erdal, G., Esengün, K., 2008. Tokat İlinde balık tüketimini etkileyen faktörlerin logit model ile analizi. Ege Üniversitesi Su Ürünleri Dergisi, 25(3): 203-209.

Girard, S., Mariajouls, C., Paquotte, P., Wisner-Bourgeois, C., 1998. An analysis of seafood consumption survey methods in France. 9th NFET Conferance-Tromso, Norway.

Gözener, B., Sayıll, M., 2013. Tüketicilerin açık süt ve süt ürünleri tüketim tercihlerinin 0ncelenmesi: TokatTurhal ilçesi örneği. Sosyal Bilimler Araştırmaları Dergisi. I, (2013): 160-175.

GTHB, 2018. Gıda, Tarım ve Hayvancılık Bakanlığı, Su ürünleri istatistikleri. (http://www.tarim.gov.tr) (Erişim Tarihi 10.04.2018).

Güngör, E. S., 2014. Erzurum Ve Van İllerindeki Balık Tüketimi Ve Tüketici Tercihleri Üzerine Bir Araştırma. Yüksek Lisans Tezi. Atatürk Üniversitesi Fen Bilimleri Enstitüsü, Erzurum. 73 s.

Gül Yavuz, G., Yasan Ataseven, Z., Gül, U., Gülaç, Z. N., 2015. Factor affecting consumer preferences on seafood consumption: The case of Ankara (in Turkish with English abstract). Yunus Research Bulletin 1: 7382.

Gürel, E., Doğan, H. G., Polat, S., Yeșilayer, N., Buhan, E., 2017. Ağrı ili merkez ilçede yaşayan bireylerin balık tüketim alışkanlıklarının belirlenmesi. Gaziosmanpașa Bilimsel Araștırma Dergisi. 6(3): 26-35.

Hatırlı, S. A., Demircan, V., Aktaş, A. R., 2004. Isparta ilinde ailelerin balık tüketiminin analizi. Süleyman Demirel Üniversitesi. İktisadi ve İdari Bilimleri Fakültesi Dergisi 9 (1): 245-256.

Karakaya, E., Kırıcı, M., 2016. Bingöl ili kent merkezinde balık eti tüketim alışkanlıklarının belirlenmesi. International Journal of Social and Economic Sciences 6 (1): 74-85.

Nalinci, S., 2013. Amasya İli Merkez İlçedeki Hane Halkının Et Tüketim Alışkanlıkları Ve Et Tüketimini Etkileyen Faktörler. Yüksek Lisan Tezi. Gaziosmanpaşa Üniversitesi Fen Bilimler Enstitüsü, Tokat. 176 s.

Olgunoğlu, İ. A., Bayhan, Y. K., Olgunoğlu, M. P., Artar, E., Ukav, İ., 2014. Adıyaman ilinde balık eti tüketim alışkanlıklarının belirlenmesi. Gıda Teknolojileri Elektronik Dergisi, 9(1): 21-25.

Onurlubaş, E., 2013. The factors affecting fish consumption of the consumers in Keşan Township in Edirne. Bulgarian Journal of Agricultural Science, 19(6): 1346-1350.

Orhan, H., Yüksel, O., 2010. Burdur ili su ürünleri tüketimi anket uygulaması. Süleyman Demirel Üniversitesi Ziraat Fakültesi Dergisi 5 (1): 1-7.

Sarı, M., Demirulus, H., Söğüt, B., 2000. Van ilinde öğrencilerin balıketi tüketim alışkanlığının belirlenmesi üzerine bir araştırma. Doğu Anadolu Bölgesi 4. Su Ürünleri Sempozyumu, 28-30 Haziran 2000, Erzurum. 627-637.

Sayılı, M., Esengün, K., Kayım, M., Akça. H., 1999. The econometric analysis of the factors affecting fish consumption in Tokat center county. Gaziosmanpaşa Üniversitesi Ziraat Fakültesi, 16: 9-27.

Saygı, H., Saka, Ş., Fırat, K., Katağan, T., 2006. İzmir merkez ilçelerinde kamuoyunun balık tüketimi ve balık yetiștiriciliğine yaklaşımı. E.Ü. Su Ürünleri Dergisi 23 (1-2): 133-138.

Şanslı, Ş., Saygl, H., 2001. Econometric model for seafood consumption. Ege Üniversitesi Su Ürünleri Dergisi, 18: $383-390$

Şen, A., 2011. Konya ve Mersin İl Merkezlerinde Yaşayan Bireylerin Balık Tüketimi Konusundaki Alışkanlık ve Bilgi Düzeylerinin Karşılaştırılması. Yüksek Lisans Tezi, Selçuk Üniversitesi Sosyal Bilimler Enstitüsü, Konya. 93 s. 
Şen, İ., Şahin, A., 2017. Mersin'de yaşayan tüketicilerin balık tüketim tercihlerini demografik faktörler açısından ele alan bir araştırma. Journal of Economics and Administrative Sciences. XIX 133-46.

Terin, M., Hamamcl, G., Gül, T., Terin, S., 2016. Van ili kentsel alanda hanelerin balık tüketim yapısı ve satın alma davranışlarının belirlenmesi. Ege Journal of Fisheries and Aquatic Sciences, 33(3): 241-249.

Turan, H., Kaya, Y., Sönmez, G., 2006. Fish meat value and place of human health (in Turkish With English Abstract). Ege Journal Of Fisheries And Aquatic Sciences, 23: 505-508.
TÜİK, 2013. Ortalama Hane Halkı İstatistikleri (www.tuik.gov.tr) Sayı:13662 13 Mayıs 2013 (Erişim tarihi: 10.04.2017)

TÜİK, 2016. Su Ürünleri İstatistikleri. (www.tuik.gov.tr) (Erişim tarihi: 10.04.2018)

TÜİK, 2017. Su Ürünleri İstatistikleri. (www.tuik.gov.tr) (Erişim tarihi: 05.07.2018)

Yüksel, F., Kuzgun, N. K., Özer, E. İ., 2011. Tunceli ili balık tüketim alışkanlığının belirlenmesi. Karadeniz Fen Bilimleri Dergisi. 2 (5): 28-36. 